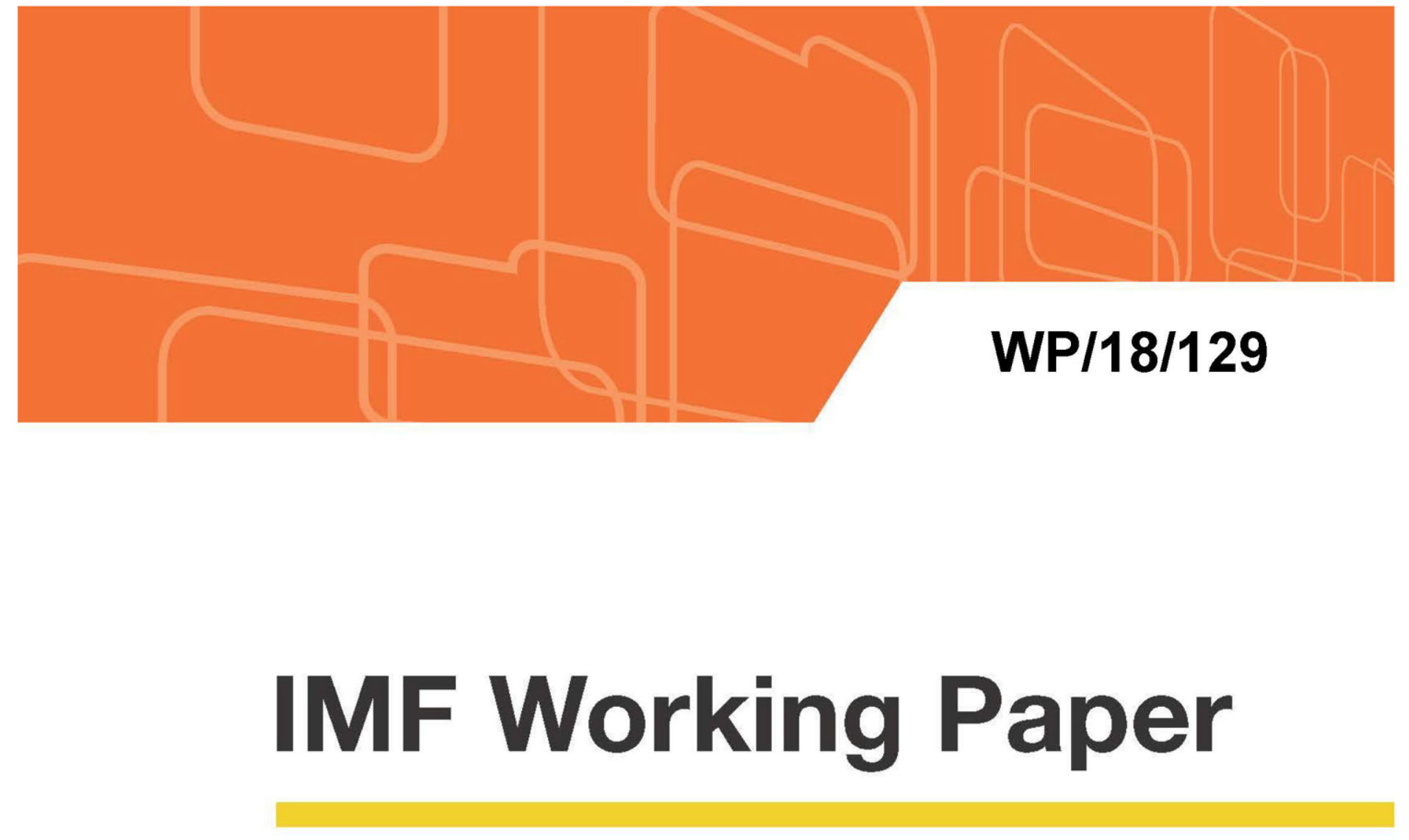

\title{
How Public Investment Could Help Strengthen Iran's Growth Potential: Issues and Options
}

by Amir Sadeghi

IMF Working Papers describe research in progress by the author(s) and are published to elicit comments and to encourage debate. The views expressed in IMF Working Papers are those of the author(s) and do not necessarily represent the views of the IMF, its Executive Board, or IMF management. 


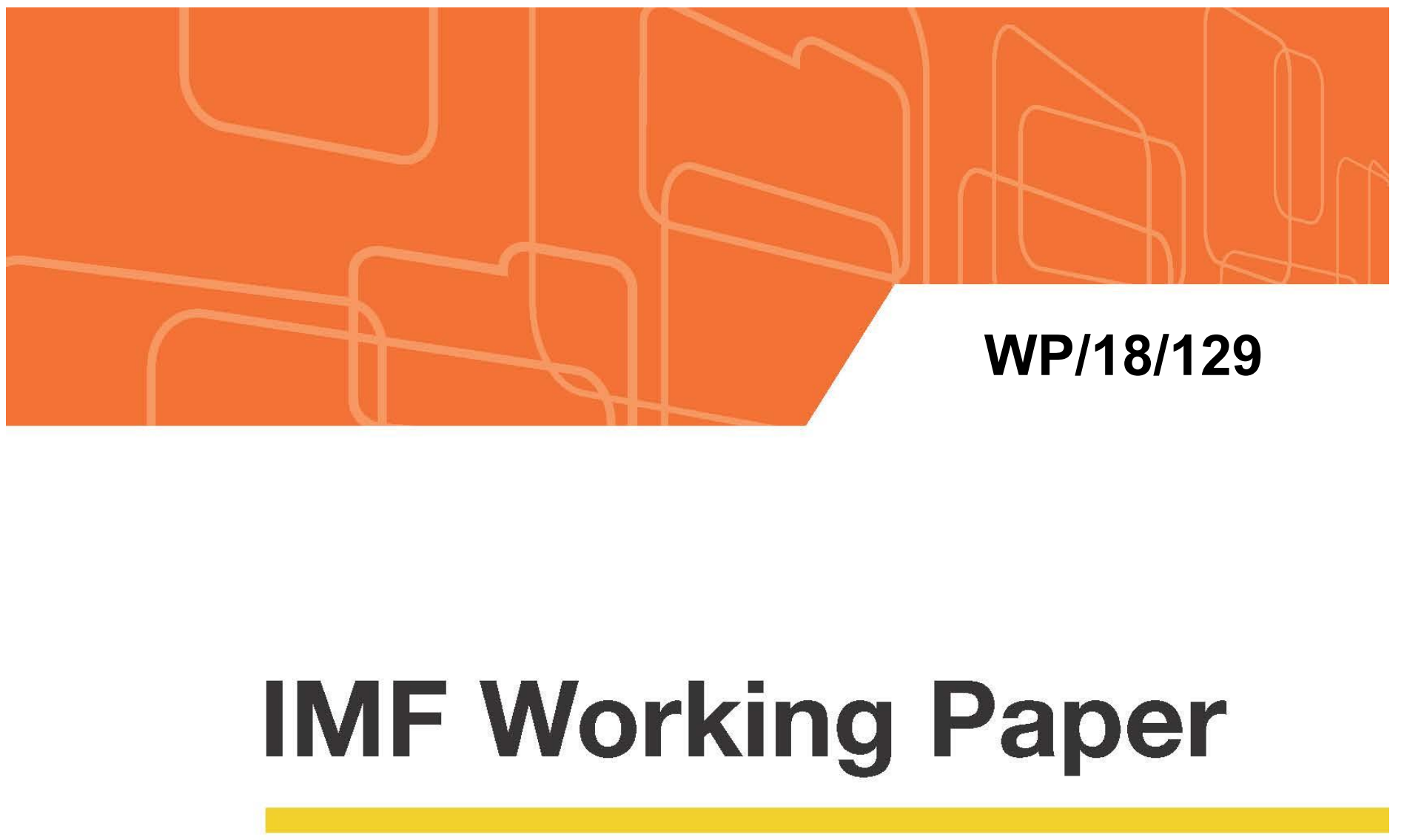

\section{How Public Investment Could Help Strengthen Iran's Growth Potential: Issues and Options}

by Amir Sadeghi

IMF Working Papers describe research in progress by the author(s) and are published to elicit comments and to encourage debate. The views expressed in IMF Working Papers are those of the author(s) and do not necessarily represent the views of the IMF, its Executive Board, or IMF management. 


\title{
IMF Working Paper
}

Middle East and Central Asia Department

\section{How Public Investment Could Help Strengthen Iran's Growth Potential: Issues and Options*}

\section{Prepared by Amir Sadeghi}

Authorized for distribution by Catriona Purfield

June 2018

IMF Working Papers describe research in progress by the author(s) and are published to elicit comments and to encourage debate. The views expressed in IMF Working Papers are those of the author(s) and do not necessarily represent the views of the IMF, its Executive Board, or IMF management.

\begin{abstract}
Public investment is key to growth in developing, oil-exporting countries, and oil revenue is an important source of finance for public investment. Looking at various approaches (gradual, aggressive, and conservative) to scaling up public investment in Iran under different oil price scenarios (baseline and adverse), this paper shows that because of absorptive capacity constraints and investment inefficiencies, the growth impact of an aggressive strategy is not significantly different from a conservative or a gradual design. Meanwhile, its costs, in terms of fiscal adjustment, are significantly higher, especially during periods when oil prices are low. Furthermore, an improvement in investment efficiency has a significant positive impact on growth outcomes and leads to higher private consumption and investment. Introducing an oil fund, on the other hand, can help contain the size of fiscal adjustments, although it results in a larger appreciation of real exchange rates and deterioration in the current account balance.
\end{abstract}

JEL Classification Numbers: E22; E62; H60; Q32

Keywords: Public Investment; Growth; Oil Revenue; Investment Efficiency; Iran Author's E-Mail Address: asadeghi@imf.org

\footnotetext{
* I am grateful to Olivier Basdevant, Selim Cakir, Christoph Duenwald, Giovanni Melina, and Catriona Purfield, for their comments and suggestions.
} 
CONTENT

PAGE

Abstract 1

I. Introduction $\underline{3}$

II. The model $\underline{5}$

III. Calibration $\underline{6}$

IV. Assessing the Growth Impact of Scaling-Up Public Investment in Iran $\underline{8}$

A. Baseline vs. Adverse Scenario ___ $\underline{8}$

B. Improvement in Public Investment Efficiency ___ $\underline{9}$

C. The Potential Role of An Oil Fund __ $\underline{9}$

V. Conclusion _ 10

Appendix _ـ 15

References __ $\underline{22}$

\section{FIGURES}

Figure 1. Weak Growth and Low Public Investment $\underline{3}$

Figure 2. Baseline vs. adverse scenario. $\mathrm{Y}$-axis is in percent deviation from the steady-state path unless stated otherwise.

Figure 3. Baseline vs. adverse scenario (continued). Y-axis is in percent deviation from the steady-state path unless stated otherwise.

Figure 4. Aggressive investment scheme and baseline oil price scenario. Y-axis is in percent deviation from the steady-state path unless stated otherwise.

14

\section{TABLES}

Table 1. Calibration of Key Parameters for Iran 


\section{INTRODUCTION}

Since the early 2000s, growth in Iran has been insufficient to improve real GDP per capita incomes. Sanctions and negative oil price shocks led to budget tightening and a contraction in pro-growth spending. Investment in infrastructure has been cut in half since 2012 (Figure 1). Looking ahead, lower public investment could constrain Iran's growth potential. On the other hand, it is possible that an increase in government revenue would be followed by an aggressive scaling up of public investment. ${ }^{1}$

The purpose of this paper is to analyze how Iran could increase its public investment to achieve higher growth while preserving a fiscally sustainable path that avoids explosive and unsustainable debt or excessively tight tax policies that would be impossible for the government to maintain in the long run. Fundamentally, a relaxation of the fiscal stance to finance a large temporary increase in investment faces two hurdles. First, scaling up too abruptly leads to inefficiencies. For example, selected projects may be of lower quality, making the entire process more inefficient (Pritchett, 2000; Dabla-Norris et al., 2012; Gupta et al., 2014, Qu et al., 2014). Second, increasing investment requires building fiscal buffers, so that in case of adverse shocks, such as an unexpected decrease in oil revenue, the

Figure 1. Weak Growth and Low Public Investment
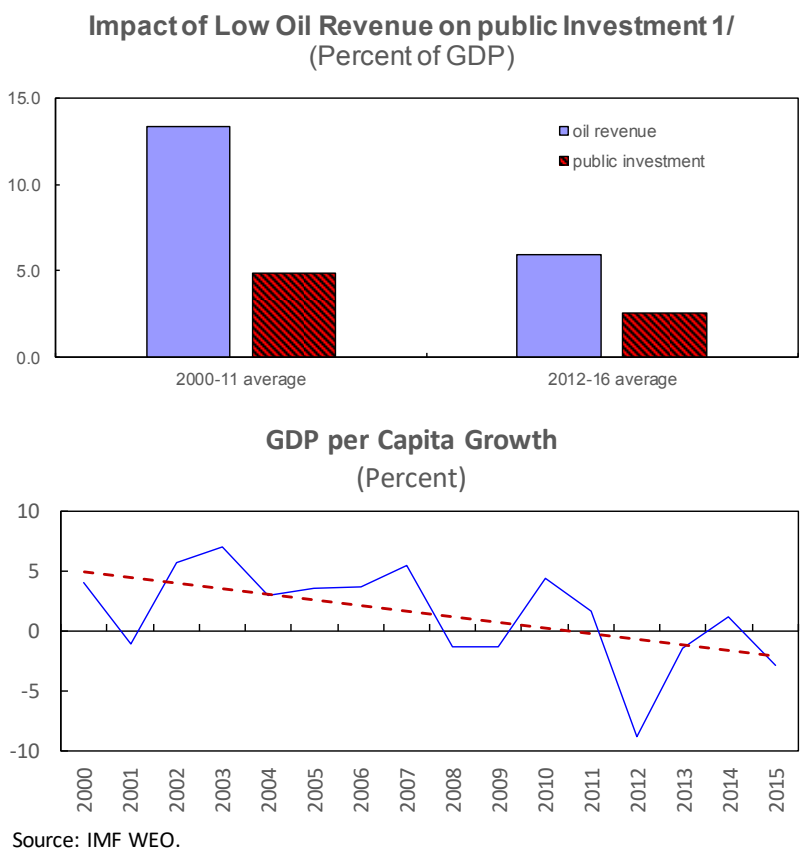

Note: 1 / Public investment is net acquisition of nonfinancial assets in annual budget. investment plan could still be carried out without compromising fiscal stability. Furthermore, scaling up investment may shift financial resources from the private to public sector and have a distortionary effect by increasing interest rates and crowding out private investment.

To that end, I define and examine multiple scenarios for investment scaling-up: (1) a "gradual" scenario, in which investment would increase by 3 percent of GDP over four years and would then remain stable at its 10-year, pre-sanctions (2002-2011) average of 5.2 percent of GDP; (2) a "conservative" scenario, in which the same amount of increase in public investment takes place

\footnotetext{
${ }^{1}$ Fiscal policy in developing, oil-exporting countries is usually procyclical (Ilzetzki and Vegh, 2008; Villafouerte and Lopez-Murphy, 2010; Arezki and Ismail, 2010) and fiscal positions usually deteriorate during oil price booms (or improve when oil prices decline), owing to expansions (contractions) in government expenditure beyond the increase (decrease) in government revenue (Villafouerte and Lopez-Murphy, 2010).
} 
over eight years, instead of four, before it reaches the same long-run level as in the gradual scenario; and (3) an "aggressive" scenario that, in three years, leads to the highest level of public investment in Iran in two decades, before stabilizing at the long-run level of 5.2 percent of GDP.

I also define two oil price scenarios: In the "baseline" scenario, oil prices are assumed to reach $\$ 55$ a barrel by 2021, while under the "adverse scenario," oil prices never exceed $\$ 48$ a barrel.

Finally, I examine investment in an "efficient" scenario, where it is assumed that the share of nominal investment that turns into productive capital is larger, allowing us to study the growth impact of structural reforms that improve public investment efficiency when oil prices are low. I also look at the "oil fund" scenario, in which the government can deplete the National Development Fund of Iran (NDFI) ${ }^{2}$ completely. It enables us to analyze the impact of such a mechanism when oil prices are low. ${ }^{3}$

While the analysis shows that scaling up investment is viable under all scenarios, since gross debt remains on a declining path in the long run and accumulating wealth continues, the costs of an aggressive strategy are considerable. An aggressive frontloading of public investment results in 0.9 percentage points ( $\mathrm{pp}$ ) of higher growth, relative to the growth that can be achieved under the gradual scenario. However, that comes at the cost of a 1 pp higher consumption tax rate than what would be needed with the gradual approach ${ }^{4}$ ( $2 \mathrm{pp}$ in the adverse scenario) and 4 pp higher accumulation rate of public debt in the short run (10 pp in the adverse scenario). Furthermore, there will be a larger appreciation in the real exchange rate under the aggressive public investment scenario, eroding the competitiveness of the tradables sector.

The costs are higher when aggressive public investment coincides with a period of low oil prices (adverse scenario). However, the government is better off with an aggressive investment approach when the oil price is persistently low, if it can improve the efficiency of public investment. Alternatively, when public investment is twice as efficient as in the baseline, the margin of growth, due to expansion in public investment, is larger: $2.1 \mathrm{pp}$ vs. $1.0 \mathrm{pp}$ in the adverse scenario. Rising efficiency does not help with the size of fiscal adjustment that is required to close the fiscal gap. Furthermore, government can also use the oil fund to decrease the size of the adjustment needed to finance the scaling up of capital expenditures. If full depletion of the oil fund is allowed, the increase in the consumption tax rate, which is needed to close the fiscal gap, will be less than $0.3 \mathrm{pp}$ (compared to $2 \mathrm{pp}$ in the adverse scenario), and gross

\footnotetext{
${ }^{2}$ NDFI is an off-budget oil fund that currently receives 20 percent of oil income annually.

${ }^{3}$ In the baseline, the model assumes government must maintain a minimum of 10 percent of GDP in the NDFI.

${ }^{4}$ In this model, there are various fiscal tools that government can use to finance expansion in capital expenditure, such as raising consumption or labor income taxes, cutting spending, cutting household transfers, or a combination of these. Furthermore, the government can burrow domestically, internationally, or take concessional loans. In this paper, I only use the consumption tax for fiscal adjustment because the difference in the impact of different financing methods on the endogenous variables of the model, specifically on growth, remains limited. Moreover, debt financing is not considered in this paper due to Iran's limited access to international financial markets.
} 
debt will increase by only $1 \mathrm{pp}$ (compared to $10 \mathrm{pp}$ in the adverse scenario) because the government fully utilizes its financial assets. The depletion of the oil fund, however, comes with other costs, such as large appreciation of the real exchange rate and current account deficit. It will also make the economy more vulnerable to exogenous oil price shocks and compromises the stability of the macroeconomy in the medium and long run. An oil fund is necessary to smooth government consumption, and without one the swings in government revenue will transfer the volatility in the global oil prices to the economy, especially if access to international debt markets are limited (van der Ploeg, 2011).

The model has been previously applied to Mozambique (Melina and Xiong, 2013), Kazakhstan (Minasyan and Yang, 2013), Chad (IMF, 2014), and to Côte d'Ivoire, Guinea, Liberia, and Sierra Leone (Deléchat et al., 2015). A similar model has also been applied to Mongolia (Li et al., 2017).

The remainder of the paper is organized as follows: Section II introduces the model and explains its features that are important for analyzing the dynamics of growth and capital expenditure in Iran. Section III discusses the calibration issues. The results are reported in Section IV, and Section V concludes the paper.

\section{THE MODEL}

The paper employs a small open real economy model with fiscal policy, à la Melina et al. (2016). The model has features of the debt model of Buffie et al. (2012) and the natural resource model of Berg et al. (2013). It includes a resource fund and a range of fiscal tools, such as consumption tax, income tax, and government spending, which is further divided into consumption, investment, and transfers. The model also contains resource-abundant developing economy features, such as absorptive capacity constraint and public investment inefficiency, which makes the model suitable to study Iran. In the discussion below, I provide a non-technical explanation of the model; technical details are included in the appendix.

The model contains two types of households: optimizing households, who own firms and receive firm profits and can decide how much to spend each period and how much to save for the future, and hand-to-mouth households, who spend all their earnings each period. Households consume a basket of tradable and non-tradable goods and supply labor to both the tradable and non-tradable sectors of the economy. By solving the household problem, I obtain the demand for goods and labor supply.

There are three sectors in the economy: non-tradable goods, tradable goods, and an oil sector. Non-oil sector firms maximize their profits in a perfectly competitive environment where they determine their demand for labor and private capital, and the production function determines the supply of goods. Firms depend also on public capital to produce goods. Private capital accumulation is subject to adjustment costs. Furthermore, the gross return on capital is taxed, although part of it is rebated to optimizing households in order to help the model capture the 
distortions in developing countries that discourage firms from investing and match the relatively low investment-to-GDP ratios observed in developing countries. Finally, productivity in the tradable goods sector is subject to learning-by-doing externalities. The oil sector is assumed to be exogenous, for simplicity. Under the assumption that oil production is capital intensive and much investment is financed by foreign direct investment, oil output follows an exogenous process. Under the assumption that oil price is given for Iran, it is set to be exogenous.

The government uses tax and oil revenues to finance public investment, purchases, and transfers. It can also borrow domestically and internationally. ${ }^{5}$ Government purchases contain non-tradable and tradable goods, and the government consumption price index is similar to households. To account for the fact that only a fraction of total public investment typically turns into productive capital - either due to inefficiencies inherent in the investment process (Pritchett, 2000; Hulten, 1996) or because governments in developing, resource-rich countries usually spend beyond the absorptive capacity of the economy during commodity price booms - the effective public investment concept is introduced. This concept stipulates that as public investment increases, the rate of expansion in effective public investment declines, reflecting the absorptive capacity constraint.

The model also features an oil fund, which allows the government to save oil revenue that is beyond what is needed in a period to close the fiscal gap. In this model, the fiscal imbalances can be covered by withdrawing from the oil fund and using one or a combination of other fiscal policy tools available in the model, such as changing the rate of consumption or income tax, cutting or expanding public consumption, and reducing or expanding transfers to households. Moreover, the model allows our analysis to impose a pre-determined ceiling on how much consumption and income tax rates can be raised or a pre-determined floor on how much public consumption and transfers can be cut. Finally, there are fiscal rules introduced in the model that allow to control the speed of fiscal adjustments needed to close the fiscal gap.

\section{Calibration}

The model is calibrated to Iran. The path for oil production starts at 4 million barrels per day and increases to 5.5 million barrels by 2030 . The oil price starts at $\$ 43$ a barrel and increases to $\$ 55$ by 2021 . Under the adverse scenario, the oil price will never surpass $\$ 48$ a barrel. The model is annual, and the simulation period is 15 years, from 2016-2030. The baseline calibration reflects the 2002-2011 average. Table 1, which appears later in the paper, summarizes the baseline calibration, which includes the following elements:

National accounting. According to the IMF World Economic Outlook database, the 2002-2011 average trade balance is 2 percent of GDP, government consumption and public investment are set at 11 and 2.2 percent of GDP, respectively, and private investment is set at 10 percent of

\footnotetext{
${ }^{5}$ International borrowing is very limited for Iran and is not considered in this paper.
} 
GDP. We opted to set the shares of traded goods at 50 percent in private consumption and 40 percent in government purchases, as government consumption typically constitutes a larger component of nontraded goods than private consumption. The share of natural resources is assumed to be 10.5 percent of GDP at the initial steady state.

Assets, debt and grants. Iran has no concessional or external commercial debt, and domestic debt is 15.7 percent of GDP.

Interest rates. The annual interest rate on domestic debt is 15 percent. Consistent with stylized facts, domestic debt is assumed to be more costly than external commercial debt. We fix the real annual risk-free interest rate at 4 percent. The real interest rate on external commercial debt is 6 percent, and concessional loans are interest free. The annual real return on international financial assets in the oil stabilization fund is set at 2 percent.

Private production. The labor income shares in the nontraded and traded good sectors is 45 and 60 percent, respectively. In both sectors, private capital depreciates at an annual rate of 10 percent. Following Berg et al. (2013), we assume a minor degree of learning-by-doing externality in the traded good sector: $\rho^{z, T}=\rho^{y, T}=0.1$. Also, as in Berg et al. (2010), investment adjustment costs are set to $\kappa^{N T}=\kappa^{T}=25$.

Household preferences. The coefficient of risk aversion- $\sigma=2.94-$ implies an inter-temporal elasticity of substitution of 0.34 . The model assumes a low Frisch labor elasticity of $0.10(\psi=$ 10). The labor mobility parameter is set to 1 , and the elasticity of substitution between traded and nontraded goods is $\chi=0.44$. To capture limited access to international capital markets, we set $\eta=1$ as in Buffie et al. (2012).

Measure of optimizing households. According to the Global Financial Inclusion Database (FINDEX), 92 percent of Iranians who are at least 15 years of age had an account at a financial institution in 2014, including 87 percent of women and 97 percent of men. This suggests that only 8 percent of Iranian adults are hand-to-mouth, which means that in each period they spend all they earn during that timeframe. However, to avoid potential overestimation, I set the share of optimizing households $\omega$ to 0.75 , implying that 25 percent of households spend all their income each period.

Oil Sector. Oil production shocks are assumed to be persistent with $\rho^{y^{o}}=0.9$. Based on Hamilton's (2009) estimates, we assume resource prices follow a random walk, so $\rho^{p^{O}}=1$. The royalty rate $\tau^{O}$ is set to 85 percent after subtracting 14.5 percent share of national oil companies. The royalty tax rate is calibrated to match the share of oil revenue in total revenues in the data.

Tax rates. The steady-state taxes on consumption, labor, and capital are chosen so that $\tau^{c}=$ $0.06, \tau^{l}=0.10$, and $\tau^{K}=0.15$, respectively.

Fiscal rules. The share of the oil fund is set to 10 percent of GDP, which is approximately $\$ 40$ billion to $\$ 45$ billion. Its balance cannot be negative. In the baseline calibration, I set the 
minimum balance of the oil fund to 10 percent of GDP. In an alternative scenario, I let the oil fund balance go to zero to see if it has any impact on the size of fiscal adjustment needed to weather an adverse oil price shock. Fiscal adjustments can take place through changes in consumption or income tax rates and cuts in government spending or transfers.

Public investment. In the baseline, public investment efficiency (share of investment turned into actual capital) is set to 30 percent $(\bar{\epsilon}=0.3)$. As an alternative scenario, I increase the efficiency number to 60 percent and examine its consequences for the economy. The absorptive capacity constraints start binding when public investment rises above 80 percent from its initial steady state $\left(\bar{\gamma}^{G I}=0.80\right)$. The home bias for government spending $v^{G}$ is set to 0.8 . The smaller degree of home bias in additional spending reflects that most of the goods are imported. The output elasticity to public capital $\alpha^{G}$ is set at 0.25 . The annual depreciation rate of public capital $\delta^{G}$ is set to 7 percent.

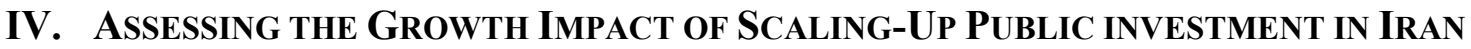

\section{A. Baseline vs. Adverse Scenario}

I calibrated the model to Iran and constructed three different scenarios for public investment scaling-up. ${ }^{6}$ Under the "gradual" scenario, investment increases by 3 percent of GDP over four years, from 2.2 to 5.2 percent, and remains stable at 5.2 percent afterwards. Under the "conservative" scenario, the same amount of increase in public investment takes place over eight years, instead of four, before reaching the long-run level of 5.2 percent of GDP. Finally, the "aggressive" scenario introduces a sharp increase in investment where capital expenditure reaches 6.5 percent of GDP, ${ }^{7}$ before stabilizing at the long-run level of 5.2 percent of GDP. Furthermore, I define two oil price scenarios. In the "baseline," the oil price gradually increases from $\$ 43$ to $\$ 55$ a barrel by 2021 , and oil production, which is currently at 4 million barrels a day, gradually increases to 5.5 billion barrels a day by 2021 . To analyze the impact of a negative oil price shock, I introduce an "adverse" scenario where the oil price will increase but does not exceed $\$ 48$ a barrel.

These scenarios illustrate the dilemma for Iran where demands may be high for a "big push" that could entail costs - by requiring further adjustment down the road—and risks that reduce fiscal

\footnotetext{
${ }^{6}$ While the model allows for us to solve for public investment endogenously, this paper analyzes an exogenouslyspecified public investment path to incorporate historical information about Iran. For example, public investment under all scenarios will converge to 5.2 percent of GDP, which is a 10 -year average of public investment (in percent of GDP) between 2002 and 2011. The highest level of public investment in the aggressive scenario, 6.5 percent of GDP, is the highest level in Iran over the last two decades.

${ }^{7}$ The level of public investment in 2008 (6.5 percent) is the highest level of public investment in Iran over the last two decades.
} 
buffers. An aggressive frontloading of public expenditures will result in a jump of $1 \mathrm{pp}$ in the consumption tax rate $^{8}$ ( $2 \mathrm{pp}$ increase in the adverse scenario) to ensure that resources would still be available to finance the investment plan, while preserving debt sustainability (

Figure 2).

Public debt jumps by $4 \mathrm{pp}$ in the short run (10 pp in the adverse scenario), although it would still be on a declining trend in the long run. Also, the accumulation of commercial debt by the government to cover scaling-up expenses, after the resource fund has reached its lower bound, will lead to higher interest rates.

At the cost of raising tax rates and debt accumulation, the cumulative (year-over-year) growth for 2016-2019, which is the period when the path for aggressive growth is higher than gradual or conservative growth, is only $0.9 \mathrm{pp}$ higher than gradual scaling up (1.0 pp higher in the adverse scenario), and it falls below gradual and conservative growth rates in the medium run, 20192024, before converging to the steady state level at 5 percent (

Figure 3). There will be a larger appreciation in the real exchange rate, when public investment is frontloaded aggressively, which causes concerns for government regarding its harmful impact on competitiveness in the tradables sector. Increased prices and wages due to increased demand for raw materials and labor in the non-traded goods sector will reinforce the "Dutch disease" effect of natural resource exploitation (Sachs and Warner 1999, Van der Ploeg, 2011).

\section{B. Improvement in Public Investment Efficiency}

The growth impact of public investment depends largely on the framework within which it is deployed (Figure 4). In an alternative scenario, when public investment is twice as efficient as in the baseline, economic growth is higher, in response to an expansion in public investment, $2.1 \mathrm{pp}$ vs. $1.0 \mathrm{pp}$ in the adverse scenario. Improving investment efficiency could be a particular hurdle for Iran, as the country still lacks the public financial management tools that ensure that investment projects are evaluated based on a cost-benefit analysis and selected accordingly. Iran could, therefore, consider first building up capacity to manage and absorb investment, a process dubbed "investing in investment" (Collier, 2011, Berg et al., 2013). The overall quality of public institutions is also crucial (Van der Ploeg and Venables, 2011, Arezki and Brueckner 2011, Arzeki et al., 2011).

\section{The Potential Role of An Oil Fund}

The NDFI plays a crucial role in how macroeconomic variables respond to public investment scaling-up (Figure 4). If full depletion of the oil fund is allowed, the increase in consumption tax

\footnotetext{
${ }^{8}$ In this model, there are various fiscal tools that government can use to finance expansion in capital expenditure: raising consumption or labor income tax, cutting spending or transfers to households, or a combination of these. In this paper, I only use the consumption tax for fiscal adjustment because the difference in the impact of different financing methods on the endogenous variables of the model, specifically on growth, remains limited. Moreover, debt financing is not considered in this paper due to Iran's limited access to international financial markets.
} 
needed to close the fiscal gap will be less than $0.3 \mathrm{pp}$ (compared to $2.0 \mathrm{pp}$ in the adverse scenario), and gross debt will increase by only $1.0 \mathrm{pp}$ (compared to $10.0 \mathrm{pp}$ in the adverse scenario). This results in the deterioration in the current account and larger appreciation of the real exchange rate, hurting the tradables sector and contributing to Dutch disease. It will also make the economy more vulnerable to exogenous oil price shocks and compromises the stability of the macroeconomy in the medium and long run.

\section{Conclusion}

Looking at various approaches (gradual, aggressive, and conservative) to scaling up public investment in Iran under different oil price scenarios (baseline and adverse), this paper finds that while scaling up investment is viable under all scenarios, the costs of an aggressive strategy are considerable. An aggressive frontloading of public investment results in $0.9 \mathrm{pp}$ of higher growth, relative to the growth that can be achieved under the gradual scenario. However, that comes at the cost of a $1 \mathrm{pp}$ higher consumption tax rate than what would be needed with the gradual approach ( $2 \mathrm{pp}$ in the adverse scenario) and $4 \mathrm{pp}$ higher accumulation rate of public debt in the short run (10 pp in the adverse scenario). Furthermore, there will be a larger appreciation in the real exchange rate under the aggressive public investment scenario, eroding the competitiveness of the tradables sector.

Structural reforms that improve the efficiency of public investment lead to larger growth margin, due to expansion in public investment: $2.1 \mathrm{pp}$ vs. $1.0 \mathrm{pp}$ in the adverse scenario. Efficiency improvements do not help with the size of fiscal adjustment that is required to close the fiscal gap. On the other hand, the utilization of financial assets, saved in an oil fund, by government helps to reduce the size of fiscal adjustments. Under the full depletion of the oil fund, the increase in the consumption tax rate, which is needed to close the fiscal gap, will be less than 0.3 $\mathrm{pp}$ (compared to $2 \mathrm{pp}$ in the adverse scenario), and gross debt will increase by only $1 \mathrm{pp}$ (compared to $10 \mathrm{pp}$ in the adverse scenario). The depletion of the oil fund, however, compromises the stability of the macroeconomy by making it vulnerable to oil price shocks.

Overall, preserving fiscal sustainability in the case of investment scaling-up is a complex task. It puts pressure on government to increase taxes which can neutralize the impact of fiscal spending on growth. It can also lead to higher debt, which can, through higher interest rates, crowd out the private sector. To overcome these challenges and ensure that investment spending supports sustainable growth, two policies could be considered. The first is to increase non-oil revenue. This would help build space for development spending while preserving overall fiscal deficit objectives. Furthermore, increasing domestic revenue would help reduce dependency on oil revenue by increasing the share of current expenditure financed by domestic taxes and allowing more oil revenue to fund public investment. The second suggested policy would be to strengthen the government investment framework to improve the efficiency of investment spending. Furthermore, bringing a long-term perspective to fiscal policy formulation, particularly through the adoption of a medium-term fiscal framework, could be very important and helpful in managing oil price shocks. 


\begin{tabular}{|c|c|c|c|c|c|}
\hline Parameter & Value & Definition & Parameter & Value & Definition \\
\hline $\exp _{\text {share }}$ & 0.24 & Exports to GDP & $\rho^{y o}$ & 0.90 & Persist. of the mining production shock \\
\hline$i m p_{\text {share }}$ & 0.22 & Imports to GDP & $\mu$ & 0.50 & User fees of public infrastructure \\
\hline$g_{\text {share }}^{c}$ & 0.11 & Govt. consumption to GDP & $\tau^{L}$ & 0.10 & Labor income tax rate \\
\hline$g_{\text {share }}^{l}$ & 0.02 & Govt. investment to GDP & $\tau^{c}$ & 0.06 & Consumption tax rate \\
\hline$i_{\text {share }}$ & 0.10 & Private investment to GDP & $\tau^{K}$ & 0.15 & Tax rate on the return on capital \\
\hline$y_{\text {share }}^{o}$ & 0.10 & Natural resources to GDP & $f_{\text {floor }}$ & $10 / 0$ & Lower bound for the stabilization fund \\
\hline$g_{\text {share }}^{T}$ & 0.40 & Share of tradables in govt. purchase & $\kappa$ & 1 & Adjust. share by external commercial debt \\
\hline$c_{\text {share }}^{T}$ & 0.50 & Share of tradables in private consumption & $\lambda 1$ & 1 & Adjust. share by consumption tax \\
\hline$R F_{\text {share }}$ & 0.10 & Stabilization fund to GDP & $\lambda 2$ & 0 & Fiscal adjust. share by labor tax \\
\hline$b_{\text {share }}$ & 0.16 & Govt. domestic debt to GDP & $\lambda 3$ & 0 & Fiscal adjust. share by govt. consumption \\
\hline$b_{\text {share }}^{*}$ & 0.02 & Private foreign debt to GDP & $\lambda_{4}$ & 0 & Fiscal adjust. share by transfer \\
\hline$d_{\text {share }}$ & 0.00 & Concessional debt to GDP & $\zeta 1$ & 0.5 & Adjust. speed of consumption tax to target \\
\hline$d_{\text {share }}^{c}$ & 0.00 & Govt. external commercial debt/GDP & $\zeta 2$ & 0.001 & Consumption tax response to debt/GDP \\
\hline$g r_{\text {share }}$ & 0.00 & Grants to GDP & $\zeta 3$ & 1 & Adjust. speed of labor tax to target \\
\hline$(R-1)$ & 0.15 & Domestic net real int. rate & $\zeta 4$ & 0 & Labor tax response to debt/GDP \\
\hline$\left(R^{R F}-1\right)$ & 0.02 & Foreign net real int. rate on savings & $\zeta 5$ & 1 & Adjust. speed of govt. consumption to target \\
\hline$\left(R^{d}-1\right)$ & 0 & Net real int. rate on concessional debt & $\zeta 6$ & 0 & Govt. consumption to debt/GDP \\
\hline$\left(R^{f}-1\right)$ & 0.04 & Net real risk-free rate & $\zeta 7$ & 1 & Adjust. speed of transfer to target \\
\hline$\left(R_{0}^{d c}-1\right)$ & 0.06 & Net real int. rate on external commercial debt & $\zeta 8$ & 0 & Transfer response to debt/GDP \\
\hline$\eta^{d c}$ & 0 & Elasticity of sovereign risk & $g_{\text {floor }}^{c}$ & $-\infty$ & Floor on real govt. consumption \\
\hline$\alpha^{N T}$ & 0.45 & Labor income share in nontraded sector & $z_{\text {floor }}$ & $-\infty$ & Floor on transfer \\
\hline$\alpha^{T}$ & 0.60 & Labor income share in traded sector & $\tau_{\text {ceiling }}^{c}$ & $+\infty$ & Ceiling on consumption tax \\
\hline$\delta^{N T}$ & 0.10 & Depreciation rate of $k_{t}^{N T}$ & $\tau_{\text {ceiling }}^{L}$ & $+\infty$ & Ceiling on labor income tax \\
\hline$\delta T$ & 0.10 & Depreciation rate of $k_{t}^{T}$ & $v$ & 0.6 & Home bias of government purchases (SS) \\
\hline$\rho y T$ & 0.10 & Learning by doing in traded sector & $v^{G}$ & 0.8 & Home bias for additional spending \\
\hline$\rho z T$ & 0.10 & Persist. in TFP in traded sector & $\alpha^{G}$ & 0.25 & Output elasticity to public capital \\
\hline$\kappa N$ & 25 & Investment adjust. cost, nontraded sector & $\delta^{G}$ & 0.07 & Depreciation rate of public capital \\
\hline$\kappa T$ & 25 & Investment adjust. cost, traded sector & $\bar{\epsilon}$ & $0.30 / 0.60$ & Steady-state efficiency of public investment \\
\hline$\psi$ & 10 & Inverse of Frisch labor elasticity & $\varsigma^{\epsilon}$ & 25 & Severity of absorptive capacity constraints \\
\hline$\sigma$ & 2.94 & Inverse of intertemporal elasticity of substitution & $\bar{\gamma}^{G I}$ & 0.80 & Threshold of absorptive capacity \\
\hline$\rho$ & 1 & Intratemporal substitution elasticity of labor & $\tau o$ & 0.85 & Royalty tax rate on natural resources \\
\hline$\omega$ & 0.75 & Measure of optimizers in the economy & $\rho p o$ & 1 & Persist. of the commodity price shock \\
\hline$\chi$ & 0.44 & Substitution elast. $\mathrm{b} / \mathrm{w}$ traded/nontraded goods & $\eta$ & 1 & Elasticity of portfolio adjustment costs \\
\hline
\end{tabular}

Table 1. Calibration of Key Parameters for Iran 


\section{Baseline Scenario}

Oil Price (US dollar a barrel)

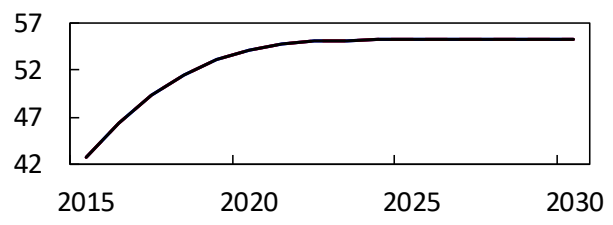

Public Investment (\% dev)

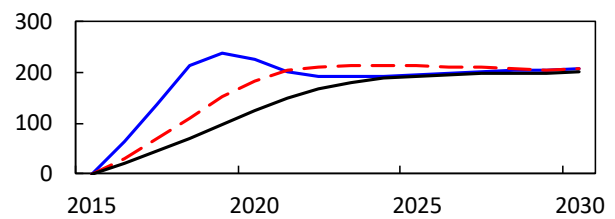

Oil Revenue (\% Total Revenue)

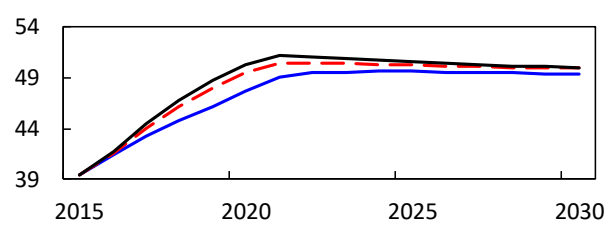

Total Public Debt (\% GDP)

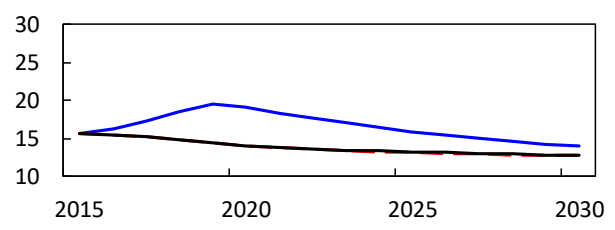

Consumption Tax Rate (\%)

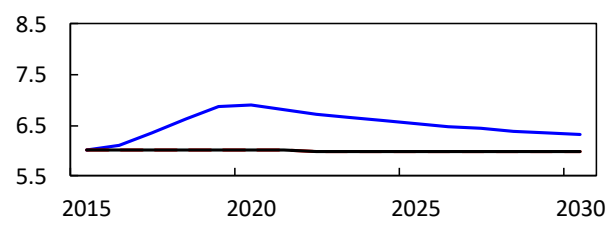

Oil Fund (\% GDP)

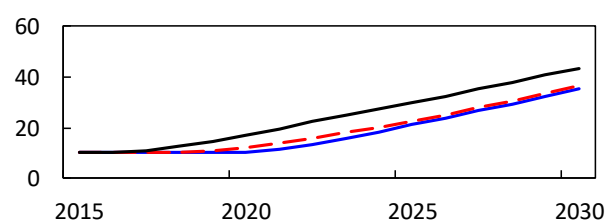

Adverse Scenario

Oil Price (US dollar a barrel)

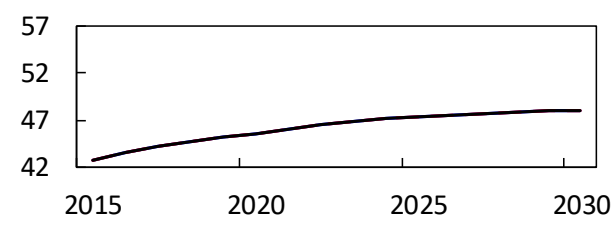

Public Investment (\% dev)

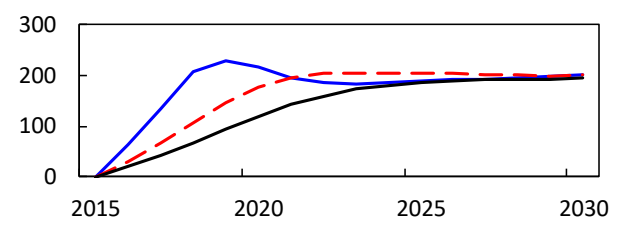

Oil Revenue (\% Total Revenue)

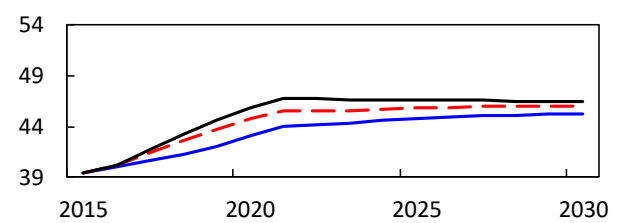

Total Public Debt (\% GDP)

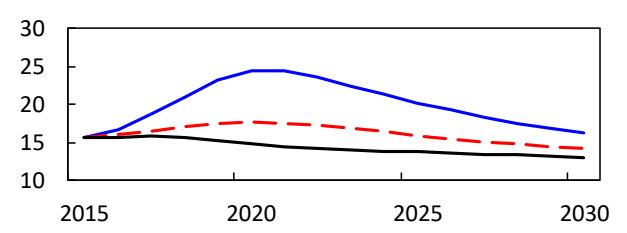

Consumption Tax Rate (\%)

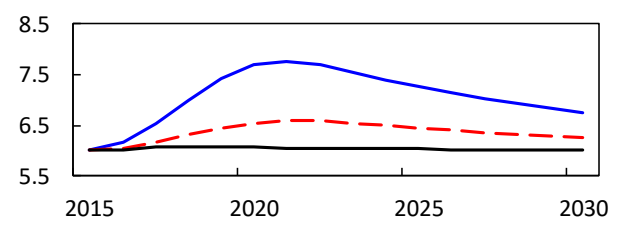

Oil Fund (\% GDP)

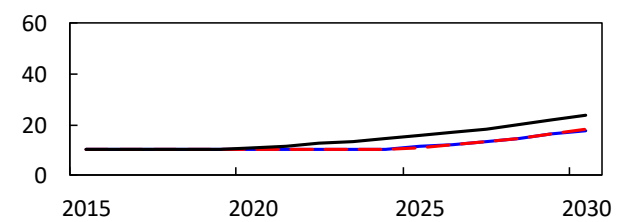

-aggressive - gradual - conservative

Figure 2. Baseline vs. adverse scenario. $\mathrm{Y}$-axis is in percent deviation from the steady-state path unless stated otherwise. 


\section{Baseline Scenario}

GDP Growth (\%)

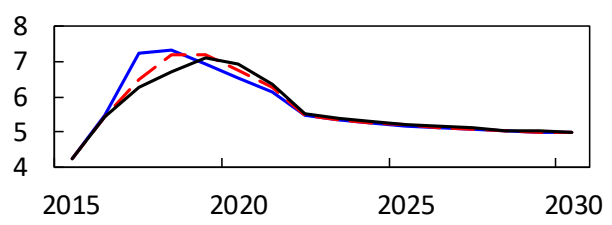

Non-Oil GDP Growth (\%)

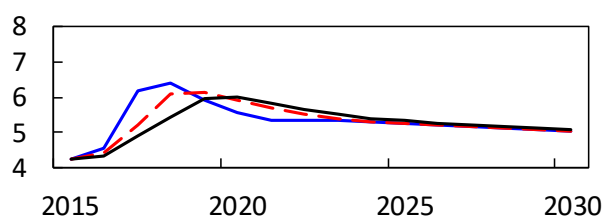

Real Exchange Rate (\% dev)

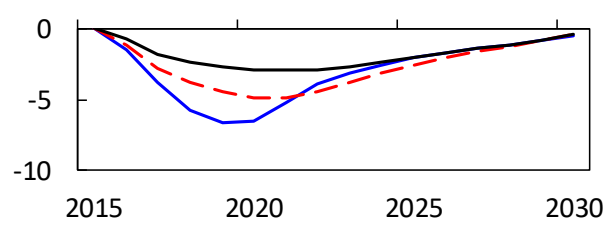

Private Investment (\% dev)

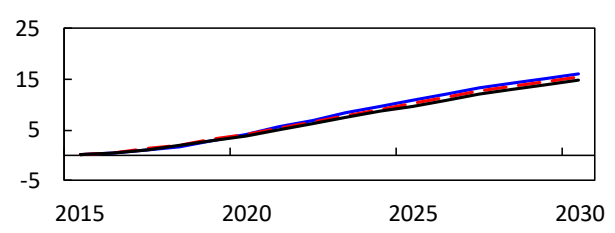

Private Consumption (\% dev)

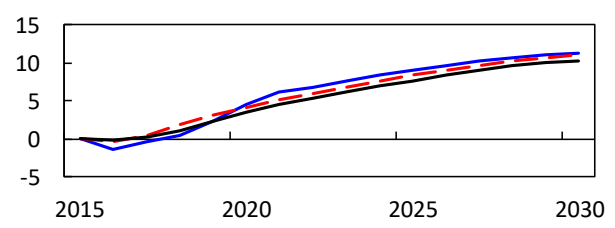

Current Account Balance (\% GDP)

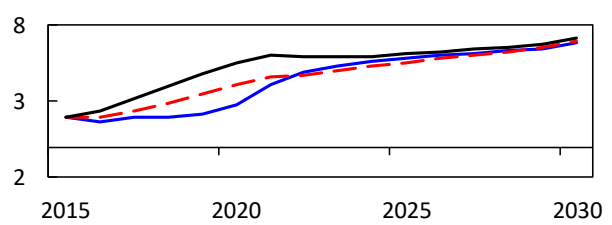

Adverse Scenario

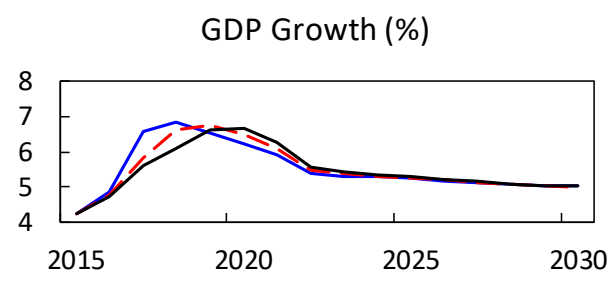

Non-Oil GDP Growth (\%)

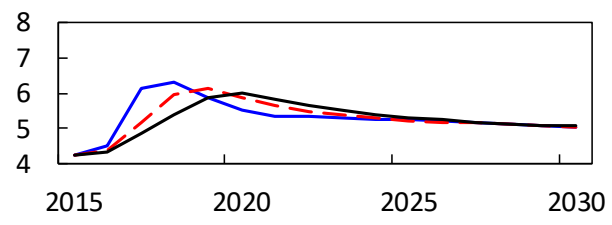

Real Exchange Rate (\% dev)

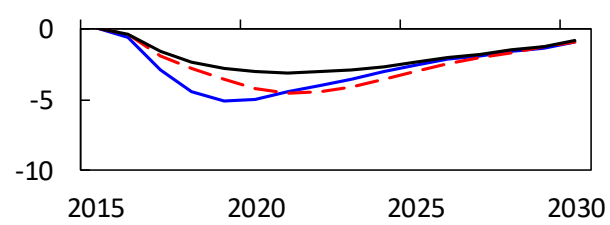

Private Investment (\% dev)

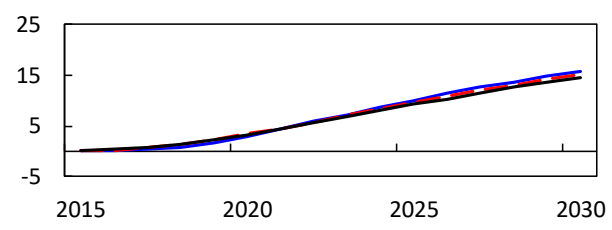

Private Consumption (\% dev)

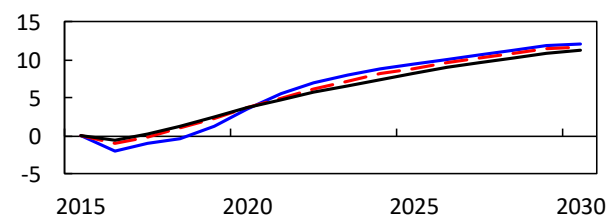

Current Account Balance (\% GDP)

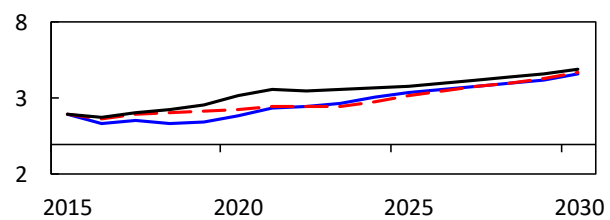
- aggressive - gradual - conservative

Figure 3. Baseline vs. adverse scenario (continued). Y-axis is in percent deviation from the steady-state path unless stated otherwise. 
Pub. Investment Efficiency (\%)

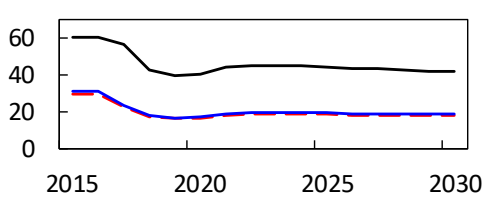

Public Investment (\% dev)

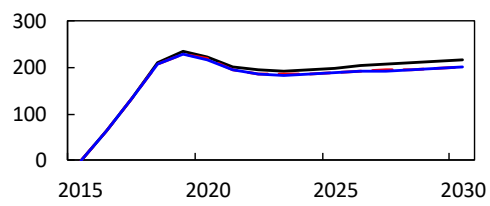

Oil Revenue (\% Total Revenue)

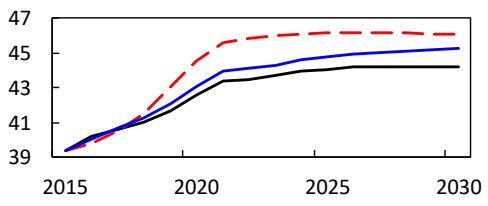

Total Public Debt (\% GDP)

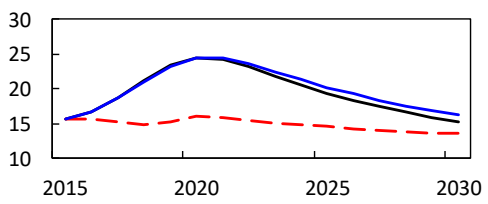

Consumption Tax Rate (\%)

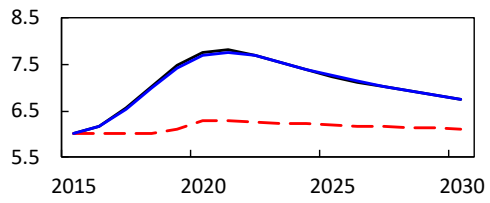

Oil Fund (\% GDP)

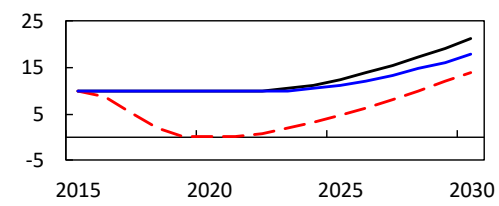

GDP Growth (\%)

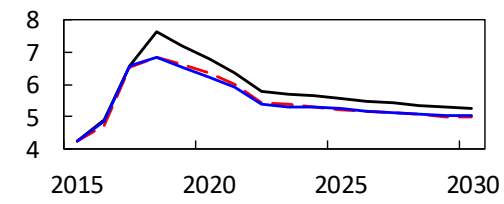

Non-Oil GDP Growth (\%)

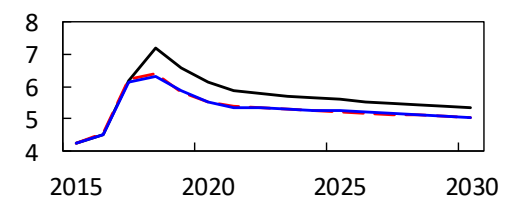

-baseline - oil fund - efficient
Real Exchange Rate (\% dev)

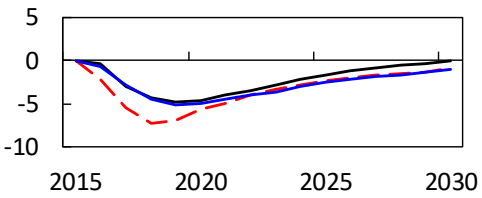

Private Investment (\% dev)

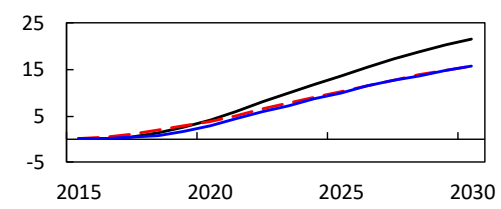

Private Consumption (\% dev)

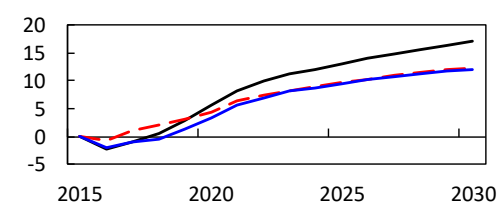

Current Account Bal. (\% GDP)

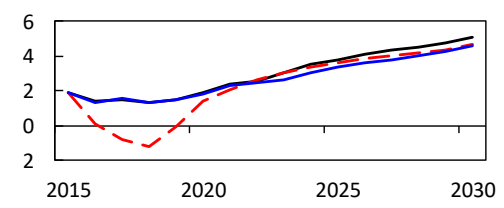

Figure 4. Baseline is an aggressive investment scheme under an adverse oil price scenario. Yaxis is in percent deviation from the steady-state path unless stated otherwise. 


\section{APPENDIX}

The appendix explains the model in details.

\section{A. Household}

There are two types of households. A fraction $\omega$ receive firm profits and have access to capital market (optimizers), and the rest, $1-\omega$, are hand-to-mouth households who spend what they earn each period (non-optimizers).

\section{Consumption}

Both types of households consume a CES basket of tradable and non-tradable goods

$$
c_{t}=\left[\varphi^{\frac{1}{\chi}}\left(c_{t}^{N T}\right)^{\frac{\chi-1}{\chi}}+(1-\varphi)^{\frac{1}{\chi}}\left(c_{t}^{T}\right)^{\frac{\chi-1}{\chi}}\right]^{\frac{\chi}{\chi-1}}
$$

where $\chi$ denotes the intertemporal elasticity of substitution and $\varphi$ the degree of home bias. Under the assumption that composite consumption is numeraire and that the law of one price holds for traded goods, and $s_{t}$ is the relative price of traded goods to composite consumption, the CES basket implies that the price of one unit of composite consumption is

$$
1=\left[\varphi\left(p_{t}^{N T}\right)^{1-\chi}+(1-\varphi)\left(s_{t}\right)^{1-\chi}\right]^{\frac{1}{1-\chi}}
$$

\section{Labor}

Households supply labor to both traded and non-traded goods sectors where there is imperfect labor mobility

$$
l_{t}=\left[\delta^{-\frac{1}{\rho}}\left(l_{t}^{N T}\right)^{\frac{\rho+1}{\rho}}+(1-\delta)^{-\frac{1}{\rho}}\left(l_{t}^{T}\right)^{\frac{\rho+1}{\rho}}\right]^{\frac{\rho}{\rho+1}}
$$

where $\delta$ is the share of labor in the non-tradables sector in the initial steady state and $\rho>0$ governs labor sectoral mobility. The real aggregate wage rate is given by

$$
w_{t}=\left[\delta\left(w_{t}^{N T}\right)^{1+\rho}+(1-\delta)\left(w_{t}^{T}\right)^{1+\rho}\right]^{\frac{1}{1+\rho}}
$$

\section{Non-Optimizer Household}

The representative non-optimizer maximizes the following utility function 


$$
U\left(c_{t}^{N O}, l_{t}^{N O}\right)=\frac{1}{1-\sigma}\left(c_{t}^{N O}\right)^{1-\sigma}-\frac{\kappa^{N O}}{1+\psi}\left(l_{t}^{N O}\right)^{1+\psi}
$$

subject to the following budget constraint

$$
\left(1+\tau_{t}^{c}\right) c_{t}^{N O}=\left(1-\tau_{t}^{l}\right) w_{t} l_{t}^{N O}+s_{t} m_{t}^{*}+z_{t}-\mu k_{t-1}^{G}
$$

where $\tau^{c}$ and $\tau^{l}$ are consumption and income tax rates, $m^{*}$ is remittances, $z$ is government transfers, $\mu$ is user fee for consumption of public (capital) services, $k^{G}$.

\section{Optimizer Household}

The representative optimizing household maximizes the following discounted present-value utility function

$$
E_{0} \sum_{t=0}^{\infty} \beta^{t} U\left(c_{t}^{O}, l_{t}^{O}\right)=E_{0}\left[\sum_{t=0}^{\infty} \beta^{t}\left(\frac{1}{1-\sigma}\left(c_{t}^{O}\right)^{1-\sigma}-\frac{\kappa^{O}}{1+\psi}\left(l_{t}^{O}\right)^{1+\psi}\right)\right]
$$

subject to the following budget constraint

$$
\begin{aligned}
& \left(1+\tau_{t}^{c}\right) c_{t}^{O}+b_{t}+s_{t} b_{t}^{*} \\
& =\left(1-\tau_{t}^{l}\right) w_{t} l_{t}^{O}+i_{t-1} b_{t-1}+i_{t-1}^{*} s_{t} b_{t-1}^{*}+\Omega_{t}^{N T}+\Omega_{t}^{T}+s_{t} m_{t}^{*}+z_{t}-\mu k_{t-1}^{G}
\end{aligned}
$$

where $b$ and $b^{*}$ are domestic and foreign bonds owned by optimizing household, which pay interest after one period at $i$ and $i^{*}$ rates, $\Omega^{x}$ is profit households receive from firms in the tradables and non-tradables sectors. Furthermore, the model includes tax rebates on taxes levied on capital return and an adjustment cost associated with foreign assets and liabilities, $b^{*} .{ }^{9}$ the parameters in the utility function $\sigma, \psi$ are the inverse elasticity of intertemporal substitution for consumption and labor supply, $\kappa$ and $\beta$ are disutility weight on labor and a subjective discount factor. $E_{0}$ is expectation operator that along with $\beta$ calculate the present discounted value of all the expected future utilities.

\section{B. Firm}

There are two types of firms, a firm that produces tradable goods and one that produces nontradables..$^{10}$ Both types of firms use labor, private and public capital.

\footnotetext{
${ }^{9}$ Including tax rebates and portfolio adjustment costs improve the model to match the data better. It also ensures stationarity as discussed in Schmidt-Grohe and Uribe (2003).

${ }^{10}$ Natural resource is assumed to be exogenous.
} 


\section{Non-Traded Goods Sector}

The non-tradables sector is perfectly competitive, and the representative firm uses the following production technology:

$$
y_{t}^{N T}=z^{N T}\left(k_{t-1}^{N T}\right)^{1-\alpha^{N T}}\left(L_{t}^{N T}\right)^{\alpha^{N T}}\left(k_{t-1}^{G}\right)^{\alpha^{G}}
$$

where $z^{N T}$ is productivity parameter and $\alpha^{G}>1$ is output elasticity with respect to public capital. Constant returns to scale is assumed for other production inputs, labor and private capital. $^{11}$

The law of motion for private capital includes investment adjustment costs

$$
k_{t}^{N T}=\left(1-\delta^{N T}\right) k_{t-1}^{N T}+\left[1-\frac{\kappa^{N T}}{2}\left(\frac{i_{t}^{N T}}{i_{t-1}^{N T}}-1\right)^{2}\right] i_{t}^{N T}
$$

$i_{t}^{N T}$ represents investment expenditure in the non-tradables sector, $\delta^{N T}$ is capital depreciation rate, and $\kappa^{N T} \geq 0$ is a cost adjustment parameter.

The representative firm in the non-tradables sector maximizes the following discounted presentvalue profit function weighted by the household's marginal utility $\lambda$

$$
E_{0} \sum_{t=0}^{\infty} \beta^{t} \lambda_{t} \Omega_{t}^{N T}=E_{0} \sum_{t=0}^{\infty} \beta^{t} \lambda_{t}\left(p_{t}^{N T} y_{t}^{N T}-w_{t}^{N T} l_{t}^{N T}-i_{t}^{N T}-\tau^{K} r_{t}^{K, N T} k_{t-1}^{N T}\right)
$$

where $r_{t}^{K, N T}=\left(1-\alpha^{N T}\right) p_{t}^{N T}\left(\frac{y_{t}^{N T}}{k_{t-1}^{N T}}\right)$ is the gross return on capital. The last term on the righthand side captures the distortions in developing countries that discourage firms from investing. It helps match the relatively low investment to GDP ratios observed in developing countries. for simplicity, part of these taxes is rebated to optimizing households, who own the firms.

\section{Traded Goods Sector}

The tradables sector is also perfectly competitive, and the representative firm uses the following production technology

$$
y_{t}^{T}=z_{t}^{T}\left(k_{t-1}^{T}\right)^{1-\alpha^{T}}\left(L_{t}^{N T}\right)^{\alpha^{T}}\left(k_{t-1}^{G}\right)^{\alpha^{G}}
$$

Productivity in the tradables sector is subject to learning-by-doing externalities

${ }^{1111}$ See, for example, Baxter and King (1993) and Kamps (2004) for similar specifications. 


$$
\ln z_{t}^{T}=\rho^{z, T} \ln z_{t-1}^{T}+\rho^{y, T} \ln y_{t-1}^{T}
$$

where $\rho^{z, T}, \rho^{y, T} \leq 1$ control the severity of Dutch disease (Matsuyama, 1992; Krugman, 1987). Similar to non-tradables sector, private capital evolves according to

$$
k_{t}^{T}=\left(1-\delta^{T}\right) k_{t-1}^{T}+\left[1-\frac{\kappa^{T}}{2}\left(\frac{i_{t}^{T}}{i_{t-1}^{T}}-1\right)^{2}\right] i_{t}^{T}
$$

and each firm maximizes its discounted present-value profit

$$
E_{0} \sum_{t=0}^{\infty} \beta^{t} \lambda_{t} \Omega_{t}^{T}=E_{0} \sum_{t=0}^{\infty} \beta^{t} \lambda_{t}\left(p_{t}^{T} y_{t}^{T}-w_{t}^{T} l_{t}^{T}-i_{t}^{T}-\tau^{K} r_{t}^{K, T} k_{t-1}^{T}\right)
$$

\section{Natural Resource Sector}

Under the assumption that natural resource production is capital intensive and there is significant resource investment in developing, resource-rich countries financed by foreign direct investment, oil production follows an exogenous process:

$$
\frac{y_{t}^{O}}{y^{O}}=\left(\frac{y_{t-1}^{O}}{y^{O}}\right)^{\rho^{y^{O}}} \exp \left(\varepsilon_{t}^{y^{o}}\right)
$$

where $\rho^{y^{o}} \leq 1$ and $\varepsilon_{t}^{y^{o}} \sim$ i.i.d. $N\left(0, \sigma_{y^{o}}^{2}\right)$ specifies the oil production shock. Under the assumption that the country output is a small portion of global supply, oil price is assumed to be exogenous which follows a similar process

$$
\frac{p_{t}^{O *}}{p^{O *}}=\left(\frac{p_{t-1}^{O *}}{p^{O *}}\right)^{\rho^{p^{O}}} \exp \left(\varepsilon_{t}^{p^{O}}\right)
$$

where $\rho^{p^{o}} \leq 1$ and $\varepsilon_{t}^{p^{o}} \sim$ i.i.d. $N\left(0, \sigma_{p^{o}}^{2}\right)$ is the oil price shock. Moreover, oil price is relative to foreign goods and so government oil revenue is

$$
T_{t}^{O}=s_{t}\left(\tau^{O} p_{t}^{O *} y_{t}^{O}\right)
$$

where $\tau^{O}$ is the royalty rate. ${ }^{12}$

\footnotetext{
12 This parameter is calibrated such that simulated data match the ratio of resource revenue to total government revenue.
} 


\section{Government}

Using capital letters for aggregate level, the flow government budget constraint is

$$
T_{t}^{O}+\tau_{t}^{c} C_{t}+\tau_{t}^{l} w_{t} L_{t}+s_{t} A^{*}+s_{t}\left(1+r^{*}\right) F_{t-1}^{*}=p_{t}^{G} G_{t}+Z_{t}+\left(R_{t}-1\right) B+s_{t} F_{t}^{*}
$$

where $C_{t}=\omega c_{t}^{O}+(1-\omega) c_{t}^{N O}, L_{t}=\omega l_{t}^{O}+(1-\omega) l_{t}^{N O}, F^{*}$ is the asset value of the oil fund earning a constant real interest rate $r^{*}, A^{*}$ is foreign aid, $G_{t}$ is government purchases, including government consumption $G_{t}^{C}$ and government investment $G_{t}^{I}$, with a relative price to composite consumption of goods of $p_{t}^{G}$, and $Z_{t}$ is aggregate transfers to households. $B$ is net aggregate government debt which includes three types of debt: 1) external concessional debt, 2) external commercial debt, and 3) domestic debt $b$.

\section{Government Purchases}

Government purchases (a combination of public consumption $G_{t}^{C}$ and public investment $G_{t}^{I}$ ) are a CES basket of traded and non-traded goods

$$
G_{t}=\left[v_{t}^{\frac{1}{\chi}}\left(G_{t}^{N T}\right)^{\frac{\chi-1}{\chi}}+\left(1-v_{t}\right)^{\frac{1}{\chi}}\left(G_{t}^{T}\right)^{\frac{\chi-1}{\chi}}\right]^{\frac{\chi}{\chi-1}}
$$

with the same elasticity of substitution between tradables and non-tradables as private

consumption. Government consumption price index, in terms of composite consumption basket, is also similar to household's

$$
p_{t}^{G}=\left[v_{t}\left(p_{t}^{N T}\right)^{1-\chi}+\left(1-v_{t}\right)\left(s_{t}\right)^{1-\chi}\right]^{\frac{1}{1-\chi}}
$$

where $v_{t}$ denotes the degree of home bias and since this analysis focuses on the expansion in public investment, the degree of home bias for additional government spending, $v^{G}$, can be different from its steady-state value $v$,

$$
v_{t}=v+\frac{p_{t}^{G} G_{t}-p^{G} G}{p_{t}^{G} G_{t}}\left(v^{G}-v\right)
$$

\section{Public Investment Efficiency and Absorptive Capacity Constrain}

According to literature, public investment usually fails to meet the expected growth in developing countries - either due to of inefficiencies inherent in the investment process (Pritchett, 2000; Hulten, 1996) or because governments in developing, resource-rich countries usually spend beyond the absorptive capacity of the economy during commodity price booms.

To incorporate this feature into the model, effective public investment $\tilde{G}_{t}^{I}$ is introduced as a function of public investment $G_{t}^{I}$, 


$$
\tilde{G}_{t}^{I}=\left\{\begin{array}{lr}
\bar{\epsilon} G_{t}^{I}, & \text { if } \bar{\gamma}_{t}^{G I} \leq \bar{\gamma}^{G I} \\
\bar{\epsilon}\left(1+\bar{\gamma}^{G I}\right) \bar{G}^{I}+\epsilon\left(\bar{\gamma}_{t}^{G I}\right)\left[1+\bar{\gamma}_{t}^{G I}-\bar{\gamma}^{G I}\right] \bar{G}^{I}, & \text { if } \bar{\gamma}_{t}^{G I}>\bar{\gamma}^{G I}
\end{array}\right.
$$

Where $\bar{\gamma}_{t}^{G I}\left(=\frac{G_{t}^{I}}{G^{I}}-1\right)$ is the public investment growth rate, relative to its steady-state value. $\bar{\epsilon} \in$ $[0,1]$ represents steady-state efficiency and $\epsilon\left(\bar{\gamma}_{t}^{G I}\right) \in(0,1]$ governs the efficiency of the portion of public investment exceeding a threshold $\bar{\gamma}^{G I}$, in percent of deviation from the initial steady state. Furthermore, $\epsilon\left(\bar{\gamma}_{t}^{G I}\right)$ takes the following form

$$
\epsilon\left(\bar{\gamma}_{t}^{G I}\right)=\exp \left(-\varsigma_{\epsilon}\left(\bar{\gamma}_{t}^{G I}-\bar{\gamma}^{G I}\right)\right) \bar{\epsilon}(24)
$$

where the parameter $\varsigma_{\epsilon} \in[0, \infty)$ adjusts the binding degree of absorptive capacity constraint. The law of motion of public capital is

$$
k_{t}^{G}=\left(1-\delta^{G}\right) k_{t-1}^{G}+\tilde{G}_{t}^{I}(25)
$$

where $\delta^{G}$ is public capital depreciation rate.

\section{The Oil Fund and the Fiscal Gap}

Introducing an oil fund allows to save the oil revenue that is beyond what is needed to close the fiscal gap in a period,

$$
F_{t}^{*}-F^{*}=\max \left\{F_{\text {floor }}-F^{*},\left(F_{t-1}^{*}-F^{*}\right)+\frac{F_{t}^{\text {in }}}{s_{t}}+\frac{F_{t}^{o u t}}{s_{t}}\right\}
$$

where $F_{\text {floor }}$ is the minimum balance that government chooses to maintain, ${ }^{13} F_{t}^{\text {in }}$ and $F_{t}^{\text {out }}$ represent the fiscal revenue (including oil revenue) and expenditure, such that fiscal deficit (surplus),

$$
\mathrm{X}_{\mathrm{t}}=F_{t}^{\text {out }}-F_{t}^{\text {in }}+s_{t}\left(F_{t}^{*}-F_{t-1}^{*}\right)
$$

can be covered by withdrawing from (saving to) the oil fund, $F_{t}^{*}-F_{t-1}^{*}$.

Furthermore, a fiscal deficit can be covered by one or a combination of other fiscal policy tools available in the model, such as raising the consumption or income tax, cutting public consumption, and/or cutting transfers to households. Moreover, the model allows one to impose a set of exogenous constraints on how much consumption and income tax rates can be raised or

\footnotetext{
${ }^{13}$ As we will see later, by changing the minimum required balance we can explore the amount of adjustment needed to close the fiscal gap, in response to scaling up investment and negative oil price shocks.
} 
public consumption and transfers cut. ${ }^{14}$ Finally, there are fiscal rules introduced in the model that allow one to control the speed of fiscal adjustments needed to close the fiscal gap and how to decide between domestic and external borrowing. ${ }^{15}$

To close the model, the non-tradables market clears,

$$
\left(p_{t}^{N T}\right)^{\chi} Y_{t}^{N t}=\varphi\left(C_{t}+I_{t}^{N T}+I_{t}^{T}\right)+v\left(p_{t}^{G}\right)^{\chi} G_{t}(29)
$$

And current account balance is

$$
\left(C_{t}+I_{t}+p_{t}^{G} G_{t}\right)-Y_{t}-s_{t}\left(r^{*} F_{t-1}^{*}+M^{*}\right)=s_{t}\left[A^{*}-\left(F_{t}^{*}-F_{t-1}^{*}\right)\right]
$$

where $I_{t}=I_{t}^{N T}+I_{t}^{T}$ is total private investment, and $Y_{t}=p_{t}^{N T} Y_{t}^{N T}+s_{t} Y_{t}^{T}+Y_{t}^{O}$ is real GDP.

\footnotetext{
${ }^{14}$ Such exogenously determined constraints reflect the feasibility of fiscal policy adjustments.

${ }^{15}$ More details on fiscal rules and fiscal policy reaction functions are available in Melina et al. (2014).
} 


\section{REFERENCES}

Arezki, R., and M., Bruckner, 2011, “Oil Rents, Corruption, and State Stability: Evidence From Panel Data Regressions,” European Economic Review, Vol. 55, No. 7, pp. 955-63.

Arezki, R., Hamilton, K., and K., Kazimov, 2011, "Resource Windfalls, Macroeconomic Stability and Economic Growth,” IMF Working Paper No. 11/142 (Washington: International Monetary Fund). Available via the Internet: www.imf.org/external/pubs/ft/wp/2011/wp11142.pdf

Arezki, Rabah and Kareem Ismail, (2010), "Fiscal Policy Responses of Oil Producing Countries to the Recent Oil Price Cycle," IMF Working Paper No.10/28, (International Monetary Fund: Washington).

Baunsgaard, T., M., Villafuerte, M., Poplawski-Ribeiro, and C. Richmond, 2012, "Fiscal Frameworks for Resource Rich Developing Countries," IMF Staff Discussion Note $\mathrm{SDN} / 12 / 04$. Available via the Internet: http://www.imf.org/external/pubs/ft/sdn/2012/sdn1204.pdf

Belinga, Vincent and Constant Lonkeng Ngouana, 2015, “(Not) Dancing Together: Monetary Policy Stance and the Government Spending Multiplier,” IMF Working Paper 15/114. International Monetary Fund, Washington, D.C.

Berg, A., Portillo, R., Yang, S., and L.-F. Zanna, 2013, "Public Investment in Resource Abundant Developing Countries" IMF Economic Review. Vol. 61, No. 1, pp. 92-129.

Buffie, E.F., Berg, A., Pattillo, C., Portillo, R., Zanna, L.F., 2012, "Public investment, growth, and debt sustainability: putting together the pieces," IMF Working Paper 12/144. International Monetary Fund, Washington, D.C.

Collier, P., 2011, "Savings and Investment Decisions in Low-Income Resource-Rich Countries." (Oxford: Center of the Study for African Economies).

Dabla-Norris, E., Brumby, J., Kyobe, A., Mills, Z., and C., Papageorgiou, 2012, "Investing in Public Investment: An Index of Public Investment Efficiency" Journal of Economic Growth, Vol. 17(3), pp. 235-66.

Deléchat, C., S. Yang, W. Clark, P. Gupta, M. Kabedi-Mbuyi, M. Koulet-Vickot, C. Macario, T. Orav, M. Rosales, R. Tapsoba and D. Zhdankin, 2015, "Harnessing Resource Wealth for Inclusive Growth in Fragile States," IMF Working Paper No. 15/25.

Esfahani, H.S., Ramirez, M.T., 2003, "Institutions, infrastructure, and economic growth.” Journal of Development Economics,” Vol 70, pp. 443-477.

Gupta, S., Segura-Ubiergo, A., and E., Flores, 2014, "Direct Distribution of Resource Revenues: Worth Considering?” IMF Staff Discussion Note SDN14/05 (Washington: International Monetary Fund). Available via the Internet: http://www.imf.org/external/pubs/ft/sdn/2014/sdn1405.pdf 
Ilzetzki, Ethan and Carlos Vegh, (2008), "Procyclical Fiscal Policies in Developing Countries: Truth of Fiction?”, NBER Working Paper 14,191, (National Bureau of Economic Research: Cambridge, Massachusetts).

IMF, 2005, Fiscal Responsibility Laws (Washington: International Monetary Fund). ,2009, Fiscal Rules_-Anchoring Expectations for Sustainable Public Finances (Washington: International Monetary Fund). Available via the Internet: www.imf.org/external/np/pp/eng/2009/121609.pdf , 2010, Strategies for Fiscal Consolidation in the Post-Crisis World (Washington: International Monetary Fund). Available via the Internet: www.imf.org/external/np/pp/eng/2010/020410a.pdf ,2014, "Chad-2013 Article IV Consultation and Assessment of Performance under the Staff-Monitored Program-Staff Report” (Washington: International Monetary Fund).

Bin Grace Li, Pranav Gupta, Jiangyan Yu, From natural resource boom to sustainable economic growth: Lessons from Mongolia, In International Economics, Volume 151, 2017, Pages 7-25, ISSN 2110-7017, https://doi.org/10.1016/j.inteco.2017.03.001.

Melina, G., S. S. Yang, and L. Zanna. 2016. "Debt Sustainability, Public Investment, and Natural Resources in Developing Countries: the DIGNAR Model," Economic Modelling, Volume 52, Part B, Pages 630-649.

Melina, G., and Y. Xiong, 2013, "Natural Gas, Public Investment and Debt Sustainability in Mozambique,” IMF Working Paper No. 13/261.

Minasyan, G. and Yang, S.C. S., 2013, "Leveraging Oil Wealth for Development in Kazakhstan: Opportunities and Challenges," Selected Issues, IMF Country Report No. 13/291, International Monetary Fund, Washington, D.C.

Pritchett, L., 2000, "The Tyranny of Concepts: CUDIE (Cumulated, Depreciated, Investment Effort) Is Not Capital” Journal of Economic Growth, Vol (5): pp. 361-84. Available via the Internet: http://piketty.pse.ens.fr/files/Pritchett00.pdf

Qu, Haonan, Martin Sommer, and SeokHyun Yoon, 2014, "Public Infrastructure Investment in the MENAP and CCA Regions," Middle East and Central Asia: Regional Economic Outlook (Washington: International Monetary Fund, April).

Sachs, J., and A., Warner, 1999, “The Big Push, Natural Resource Booms and Growth,” Journal of Development Economics, Vol. 59, pp. 43-76.

Schmitt-Grohe, S. and M. Uribe, 2003, "Closing Small Open Economy Models," Journal of International Economics, vol. 61(1), pp. 163-185.

Van der Ploeg, Frederick, 2011, "Natural Resources: Curse or Blessing?” Journal of Economic Literature, Vol. 49, No. 2, pp. 366-420. 
and Anthony J. Venables, 2011, "Harnessing Windfall Revenues: Optimal Policies for Resource-Rich Developing Economies,” The Economic Journal, Vol. 121, pp. 1-30.

Villafuerte, M. and P. Lopez-Murphy, (2010), "Fiscal Policy Responses of Oil Producing Countries to the Recent Oil Price Cycle", IMF Working Paper No.10/28, (International Monetary Fund: Washington). 